\title{
14
}

\section{The Establishment of Barnahus in Denmark: Dilemmas for Child Welfare Caseworkers}

\author{
Lene Mosegaard Søbjerg
}

\section{Introduction}

Providing a multidisciplinary and comprehensive response to child abuse is the fundamental core of the Nordic Barnahus model. In Denmark, five Barnahus were established by law in October 2013. The establishment of Barnahus was one of the several outputs of a broad legislation called "the assault package" (in Danish "overgrebspakken"), implemented as a response to the disclosure of a number of shocking cases of child neglect and abuse in Denmark during the 2010 (Glassow 2015). There were high expectations of Barnahus from politicians, experts and child welfare caseworkers (Damsgaard and Christiansen 2012). The gathering of expertise in one organisational unit and the concept of ensuring multidisciplinary and interagency collaboration between professionals and agencies dealing with the child and the child's

\footnotetext{
L.M. Søbjerg ( $\square)$

VIA University College, Aarhus, Denmark e-mail:LMOS@VIA.DK 
family in particular were thought to improve work with abused children (Sundhedsstyrelsen 2012).

Work with abused children not only takes place within the Barnahus but also between the Barnahus and collaborating agencies. In Denmark, there is an important collaboration between the Barnahus and the child welfare services in the local municipalities where the children and their families live. As described in the introductory chapter, the responsibility for Barnahus is in the Danish National Board of Social Services, which suggests a strong connection with the social welfare system. The child welfare services in municipalities have the overall legal responsibility for the children and their well-being before, during and after a case has been handled in the Barnahus. This strong connection with the child welfare system is apparently stronger in Denmark than in most of the other Nordic Barnahus models, for example, in Norway, where Barnahus is organised within the judicial system (Stefansen et al. 2012).

The Barnahus model and cooperation inside the Barnahus have been analysed in other Nordic countries (see, for instance, Conte 2014; Johansson 2012; Stefansen et al. 2012). Less attention has been given to collaboration between Barnahus and other agencies ${ }^{1}$, and consequently, it is appropriate to investigate the role of Barnahus in a broader context.

Based on the empirical study, this chapter will discuss the collaboration between the Danish Barnahus and local child welfare services, departing from a holistic perspective on social work. A holistic perspective is central to social work in Denmark, as will be explained later in this chapter. The key question explored in the chapter is, How the establishment of Barnahus has affected the experience of child welfare caseworkers regarding their ability to work holistically with an abused child and his/her family? The understanding of holism will be analysed from the perspective of caseworkers in local child welfare services who have collaborated with Barnahus in specific cases.

Initially, the chapter explains the responsibilities of Barnahus and the child welfare services in municipalities in Denmark. A set of theoretical perspectives and definitions of a holistic approach to social work are then presented before the methodology of the study undertaken among the municipalities of one Danish Barnahus is introduced. The empirical data for the study is finally analysed in light of the theoretical 
approaches of holistic social work. The focus of the analysis is the cooperation between child welfare services and Barnahus as seen from the perspective of the child welfare caseworkers dealing and cooperating with the Barnahus.

\section{Responsibilities of Barnahus and the Local Child Welfare Services}

The role of Barnahus in Denmark is to coordinate cases and assist the local child welfare services, who are responsible for providing the necessary and correct help for an abused child. If the child welfare services suspect that an assault has taken place and it is necessary to involve at least two public agencies in the case (most often this involves the police, health care system and child welfare services), the child welfare services are obliged by law to contact the local Barnahus. The involvement of Barnahus is mandatory under these circumstances, regardless of the resources and expertise of child welfare services in relation to cases of abused children ${ }^{2}$. When a suspicion of child abuse is raised, a child welfare investigation has to be made ${ }^{3}$. This child welfare investigation is made by the child welfare services who have full responsibility for the case, while the role of the Barnahus is to provide expertise, coordinate initiatives and assist in child psychiatric evaluations. This division of responsibility fits well with the general organisation of the Nordic Barnahus model, where each participating agency is responsible for its own part (Landberg 2009, 17).

\section{Theoretical Perspectives on Holistic Social Work}

A central concept in Danish social work is what will be termed "holism" or "holistic social work" in this chapter; however, holism does not completely translate and explain the core values of the terms "helhed" (meaning "whole") or "helhedsorientering" (meaning "orientation towards the whole") which are often used in Danish social work. A characterisation and explanation of the importance of holism to social work in Denmark are consequently appropriate. 
Holism is a central aspect of social work because all children, young people and adults are part of a whole, of something bigger than the individual. A holistic approach is based on the understanding that the problems of a child or young person cannot be viewed separately from the rest of the individual (Ejrnæs and Guldager 2008; Guldager 2015). Working holistically means working with all the aspects of a person's life that are important to a case, based on the assumption that all the aspects are interconnected (Harder 2011). Not all elements are equally important, but they are all significant and nothing can deliberately be left out. A holistic approach is by definition multidisciplinary, as one profession cannot be profoundly knowledgeable about all the aspects of a case (Guldager 2015).

Holism is central to social work, as explained in the words of Ferguson, because social work includes the

combination of a value base of respect, empowerment and social justice, the emphasis on a relationship between worker and service user founded on trust and non-judgmental acceptance; a knowledge base which embraces both developmental psychology and also an understanding of social structures and social procedures, and a repertoire of methods ranging from individual counselling to advocacy and community work; all these give social work a holistic perspective which makes it unique among the helping professions (Ferguson 2008).

Putting all the different concerns and topics mentioned by Ferguson together is the core of holistic social work.

Uggerhøj (2011) defines holism as "being able to see a case in as big a perspective as possible and being able to view a problem from as many angles as possible". A holistic perspective is consequently the ability of the child welfare caseworker to see a case from a broader perspective: to see a case in multiple dimensions and to act according to these multiple dimensions. The purpose of working holistically is to be able to find the right solution(s) to the child's problems. An unintended consequence of not working holistically is attempting to solve the wrong problem or trying to make a solution fit the problem rather than letting the problem(s) define the solution. 
In the case of abused children, working holistically means viewing the child not only as an abused child, but also as an individual with a multitude of possibilities and challenges which can affect the child's ability to deal with, and react to, the abuse. It is also important to acknowledge that the abused child is part of a larger whole, first and foremost a family, but also a circle of friends, a neighbourhood, a town or city and a society. In a holistic approach, the abuse cannot be viewed alone, and the child cannot be treated without consideration of the child's immediate environment. Although it is clear that the sexual or physical abuse is the central issue in a case of child abuse, the abuse is typically not the child's only concern. In a study of the effect of group therapy for sexually abused children in Denmark, the background data on the participating children showed that their life circumstances were difficult, and the children had a number of challenges in addition to the abuse. Many of the families had problems with alcohol or drug abuse, mental illness and/or unemployment (Lægsgaard and Søbjerg 2012). The fact that abused children often have multiple problems that social caseworkers have to include in their dealings with the child accentuates the importance from a social work perspective of using a holistic approach in cases of child abuse.

The opposite of holism is reductionism. Reductionism occurs when a case is viewed from a more simple or reduced perspective. From a theoretical perspective, two of the core elements of Barnahus, the cooperation of multiple professionals and specialised knowledge, pose a contradiction when analysed as part of a holistic approach. Gaining specialised knowledge on one issue inevitably leads to less focus on other issues. This can be termed reductionism, which is the opposite of holism. Laursen (2011) argues that if a holistic approach is not used, some form of reductionism is inevitably taking place; however, social problems are often complex and sometimes even wicked (meaning impossible to solve) (Rittel and Webber 1973), and in order to handle or tame these complexities, it can be necessary to employ a certain degree of reductionism. Despite the inevitable need to reduce the complexity in the field of social work, the ideal is to work holistically (Laursen 2011).

The Barnahus model also includes holistic aspects. Johansson argues that the main goals of Barnahus are "to improve the criminal 
investigations and make the judicial processes more efficient on the one hand, and to improve protection, support, and treatment on the other hand" (Johansson 2012). This involves a combination of criminal laworiented logic and treatment-oriented welfare logic. The combination of several logics in the Barnahus is an example of multi-professional cooperation, which contributes to holistic social work, because the main objective is to use a multidisciplinary effort to help the child with all aspects of the abuse. There are consequently holistic elements integrated within the Barnahus model; however, working multi-professionally is not the same as using the theoretical perspective of holistic social work presented above, because the theoretical foundation of holistic social work focuses on the child (or in more general terms, the citizen) and not the logic of organisations or professionals working with a case.

The difference between the instinct of child welfare caseworkers to see a case of child abuse from a holistic perspective and the Barnahus' more organisational objective of providing multidisciplinary specialised expertise poses a conundrum worth investigating. An ambition to analyse this dilemma was the main inspiration behind the research question presented and analysed in this chapter.

\section{Methodology and Strategy of Analysis}

The chapter draws on data from a study conducted at one of the five Barnahus in Denmark, in 2014, approximately one year after the establishment of Barnahus in Denmark.

The study included a quantitative survey distributed to all nineteen child welfare services connected to this Barnahus and semi-structured qualitative interviews with twelve child welfare caseworkers in eight municipalities. Seventeen municipalities answered the survey, which gave a response rate of $89 \%$. The quantitative data of the study provided a basis of knowledge about the Barnahus and the cooperation between the municipalities and the Barnahus; however, the written answers of the questionnaire did not elaborate on the holistic perspective on the cases, and the data included in the analysis are thus primarily based on the qualitative study. 
Eight municipalities were chosen for the qualitative part of the study, based on the size of the municipality and the number of Barnahus cases in each municipality. The municipalities represented four categories: large and small municipalities with relatively high numbers of cases, and large and small municipalities with relatively low numbers of cases. The intention was to include municipalities with variation in the numbers of Barnahus cases, not only because of differences in the size of the municipality. Two child welfare services from each of the four categories were contacted, and qualitative interviews with a child welfare caseworker and/or a manager from the child welfare services were carried out.

Five interviews were single interviews and three interviews involved two or three respondents. All interviews were recorded and transcribed verbatim. The interviews were undertaken in Danish and followed a semi-structured interview guide. The quotes in this chapter have been translated by the author. All interviews are treated anonymously.

The data were analysed in an iterative process using both a deductive and an inductive approach (Kvale 2007). First, all transcriptions were read and the identified patterns of statements led to the construction of a coding framework based on the research question. Second, an inductive reading, in which unexpected themes were discovered, was conducted. Finally, systematic coding identified recurring themes and patterns.

The analysis identified two divergent perceptions of the establishment of Barnahus. One perception was a positive reaction to the increase in expertise and attention given to child abuse. A contradictory perception was the expression of a number of dilemmas encountered when working with abused children in the child welfare services. The essence of the dilemmas is connected to the holistic approach to social work and will be analysed and discussed below.

\section{Centralisation of Competences Challenges Holism}

A holistic perspective on abused children was evident in all interviews undertaken in the study. Several child welfare caseworkers explained how an abused child is more than just the abuse, and it is important 
to have a holistic perspective in cases of child abuse. "It [the abuse] fits into a set of events in the child's life and the abuse is only a part of it" (Interview 1). The acknowledgement that the abuse is only one of many problems in an abused child's life makes it very important for the child welfare caseworkers to be able to work with the complete child.

Many caseworkers described positive expectations regarding the establishment of Barnahus. One child welfare caseworker stated that "the establishment sends an important signal that child abuse is not acceptable", and this gives the child welfare caseworkers an increased incentive to act on suspicions of child abuse (Interview 7). Several child welfare caseworkers also explained that the establishment of Barnahus gives them more confidence because they know there is a place where they can ask for help and advice. One caseworker said: "We actually have these world champions in child abuse who we can work together with" (Interview 3). There is consequently no doubt that the child welfare caseworkers had high expectations about the establishment of Barnahus and the ability of the Barnahus staff to assist the local child welfare services in their handling of cases of child abuse. The child welfare services were also very satisfied with the advice and help they received from Barnahus.

Despite an acknowledgement that the concentration of expertise leads to a higher level of knowledge and expertise, and that the quality of the services from Barnahus is very high, about half of the child welfare services participating in the qualitative study argued that the centralisation has negative side effects related to the holistic understanding of social work. One concern is that the concentration of expertise in Barnahus may drain the knowledge of local child welfare services about cases of child abuse. One child welfare caseworker said outright:

One disadvantage with the Barnahus is the centralisation. You move resources and competences away from the child welfare services (Interview 3).

Another said:

The thought of securing a systematic approach in these cases is good but securing the expertise within the child welfare services instead of 
centralizing it outside the child welfare services could have been considered (Interview 1).

Since the handling of an abused child is moved away from child welfare services to Barnahus, some child welfare caseworkers fear that there will be fewer and fewer employees in the child welfare services who actually have experience in dealing with abuse cases. They fear that a weakening of local expertise in child abuse will affect the ability of child welfare caseworkers to work holistically, because there is a risk that the focus on child abuse will be downgraded due to inadequate knowledge. Viewed from a holistic perspective, the consequence may be a sort of reductionist approach to the child, where issues of abuse are ignored, and this is not in line with a holistic perspective. This can make it more difficult to detect and expose new cases of abuse since signs of child abuse are in danger of being overlooked or ignored by the local child welfare services. An unintended negative effect could be that fewer abused children actually receive the help they need.

There is a dilemma here between holism and reductionism. The child welfare caseworkers, who work holistically, need to have knowledge about child abuse in order to do their job properly; however, it is important to recognise that half of the child welfare services interviewed did not make a direct connection between the centralisation of expertise and their ability to work holistically ${ }^{4}$.

\section{Improvement in Cooperation with Other Public Agencies}

The child welfare services greatly appreciate the close cooperation with the police which was established in relation to Barnahus and to a certain degree administered by Barnahus.

What we experience as a positive effect of this is that the cooperation with the police and the sharing of information has become much better. All of 
a sudden we get a lot more information about the family which we can use when we continue the work with the family afterwards (Interview 2).

As part of the legislative assault package mentioned in the introduction, which included the establishment of Barnahus, child welfare services now have the legal right to share information about cases across different public agencies. Several child welfare caseworkers explicitly emphasise the added value of cooperating and sharing information with the police, but information can also be shared with hospitals and other medical agencies. The right to share information is not a direct consequence of the establishment of Barnahus; however, Barnahus coordinates the meetings where information is exchanged and the meetings often take place in Barnahus, which provides Barnahus with an obvious role in this improvement of cooperation. "The sharing of knowledge has really meant a lot. It is easier to hold on to cases and follow them, when you have more information", one child welfare caseworker argued (Interview 2 ). The sharing of information consequently strengthens the ability to work holistically with abused children.

\section{Dilemmas of Involving the Police}

Although the close cooperation with other public agencies is greatly appreciated, some child welfare caseworkers see a dilemma in the involvement of the police because it can result in the fragmentation of social work with the family. Involving the police often means pressing charges, and sometimes, the child welfare caseworkers feel that involving the police clashes with the best interests of the child. The dilemma is that when the police are contacted about the suspicion of a crime against a child, the legal system steps in, child investigative interviews are conducted, and the alleged abuser and perhaps others are interviewed by the police. At times, the conclusion of these interviews is that there is not enough evidence to actually press charges, or the public attorney does not believe that a trial will end in a conviction, so the case is dismissed. If this happens, the whole family has been disrupted and the child welfare services have to continue working with the family in order to ensure 
the well-being of the child. One caseworker argued that "It may not be a case for the legal system, but there is something in the family which they need help with" (Interview 7). Another caseworker said "Our goal is to help this child. The Barnahus can help us [if the police is contacted], but sometimes the best thing is not to press charges" (Interview 5).

The predicament is that according to the legislation establishing Barnahus, a Barnahus cannot get involved if there is only one public agency involved in the case. If the child welfare services do not involve the police (which is the second public agency in most cases), the case cannot involve Barnahus. This again means that the child welfare services in the municipalities do not have access to the expertise offered in Barnahus, and this becomes an unintended effect of this predicament. Sometimes, the child welfare services would like to obtain guidance, assistance and psychological treatment in cases that they see as being in a grey zone, cases that should not be tried in a court of law, but where a child shows signs of failure to thrive and the municipality has to deal with the family. This poses a dilemma which is related to the opposition between holism and the reductionism of specialised knowledge. On the one hand, the child welfare services appreciate the opportunity to receive assistance from experts with knowledge about child abuse. On the other hand, the legal framework of Barnahus states that it is necessary to involve the police or health services in order to involve Barnahus in the case. Involving the police is often very important, but in some cases, the child welfare caseworkers found that involving the police and engaging with all the legal issues of interrogation was the wrong way to deal with a particular child and the child's family.

It is against the law to hit your child, but should the police be contacted when a child says something or only when the child has bruises, because then the police has evidence? Or should the police be contacted because you think it will help the child if the parents are punished? Sometimes when I contact the police, they are also in doubt (Interview 5).

Approaching the family from a holistic perspective and looking at the strengths and potential of the family may be a more constructive way of working with the family, according to the child welfare caseworkers. 


\section{Conflicting Approaches to Working with the Family}

The acknowledgement that abuse is one of several problems in an abused child's life, makes it very important for the child welfare caseworkers to be able to work with the child. In many child welfare services, this implies working with the whole family, not just the child. This is especially difficult in cases of child abuse, since many cases of abuse take place within the family or the child's immediate circle of trust. "Of course there are families where someone from the outside has abused the child but the majority of cases happen within the family" (Interview 8). Several caseworkers, however, argue that working with the whole family is not an integrated part of the work in a Danish Barnahus.

The coordination is around the child but the child is part of a unit called a family. When the child welfare services look at the whole picture, it [the case in Barnahus] becomes a bit fragmented compared to how we deal with the family. We cannot take care only of the child. It is not in the interest of the child if we don't take care of the family (Interview 6).

The interviews indicate that there may be a tension between the approach of child welfare services and that of Barnahus in working with the families. Several child welfare services argue that the extent of work in Barnahus is sometimes too narrowly defined, because their focus is exclusively on the abused child. The child welfare caseworkers find it challenging that Barnahus does not work holistically with the child and the child's family. "If the whole family received a collective offer of help [from Barnahus] then it would make sense, when we work to heal the family again" (Interview 6). This statement shows how child welfare services are focused on working with the child and its family rather than just the child. It was not expressed as an intended critique of Barnahus, but rather as an expression of frustration because the perspective and focus of Barnahus do not match the perspective of the child welfare caseworker. A Swedish book on Barnahus describes how the cooperation 
between all relevant professionals in a Barnahus will lead to "an unbroken chain of support where the child and its parents receive the help they need' (Landberg 2009, 79, author's translation). This description of an unbroken chain is in many ways what many Danish child welfare caseworkers are asking for, but the chain appears to have weak links because the child welfare services do not feel that the whole family receives all the help they need in Barnahus.

\section{Concluding Discussion: Common Agenda, Different Perspectives}

The simple but also multifaceted answer to the research question of how the establishment of Barnahus has affected the ability of child welfare services to work holistically is that it has affected them in several ways. The core elements of multiple professionals working together on a case, as in Barnahus, is in some ways an example of holistic social work because the child's case is viewed from several angles. The centralisation of expertise in cases of child abuse in Barnahus has clear advantages because it can provide the caseworkers with room to engage more holistically with the case at hand. Conversely, the centralisation of expertise is viewed by some as a weakness, because it drains the local child welfare services of knowledge on child abuse which may lead to a fragmentation in the treatment of the cases. Barnahus and the legislation implementing Barnahus provide productive closer cooperation between public agencies, which improves the ability to work holistically with the child. At the same time, the mandatory involvement of the police or health services in order for Barnahus to become involved leads to dilemmas about how to best protect the interest of the child, because sometimes the best interest of the child is not to involve the police. Finally, the holistic perspective means that child welfare caseworkers wish to work with the whole family which is not possible within the framework of the legislation initiating the Danish Barnahus. Consequently, child welfare caseworkers at times disagree with the focus of Barnahus. Analysed from the theoretical perspective of holistic social work, the conclusion 
is that while Barnahus contributes to holistic social work with abused children, Barnahus and the child welfare services do not embrace the same type of holistic approach to abused children. While Barnahus has an organisational holistic perspective, child welfare services have a more comprehensive child-centred holistic perspective.

The divergent perspectives on holism can be illustrated using a metaphor. Treating abused children in Barnahus is like using a pair of binoculars to view the child. Barnahus zooms in on the case of abuse and sees certain parts of the child and the child's problems clearly and in detail. Barnahus staff all see the same problem, and from this perspective, it is possible to initiate treatment and procedures to deal with the problem in focus. As long as the binoculars can retain this focus, the problem is dealt with in the best possible way. The initiatives in Barnahus are greatly appreciated and are of high quality, which is acknowledged by the child welfare services responsible for the children's well-being.

However, a large part of the child and the child's problems cannot be seen when zooming in with the binoculars. The majority of the child and the child's difficulties are outside the perspective of the binoculars. The child welfare services work closely with the child and the family and they do not use binoculars, but try to see all of the children in front of them. Child welfare services can consequently see problems and nuances that are outside the scope of Barnahus binoculars. Child welfare services see the problems that are addressed in Barnahus but they often also see a wider picture. They view this wider, more holistic perspective on the child as very important in work with abused children, and while they appreciate the knowledge obtained by using binoculars, they also argue that blocking out large parts of the child's life has unintended consequences for their social work with the abused child and its family.

Some of the differences between Barnahus and child welfare services in Denmark are not just theoretical but practical. The Danish Barnahus has been given specific tasks with a specific budget to fulfil these tasks. It is, for instance, not within the statute of Barnahus to offer services to the child in relation to problems other than the abuse, nor is it possible to offer actual family counselling or a larger degree of family support; however, these frameworks for the work undertaken within Barnahus are not necessarily 
unchangeable. Barnahus in Denmark is still a young institution, and the experiences of Barnahus are being continuously gathered in order to improve the help given to abused children (Ankestyrelsen 2015; Børnerådet 2015; Socialstyrelsen 2015). It is very important to include the perspective of the local child welfare services in discussions about an elaboration of the mandate of Barnahus in Denmark. Offering specialised help on one particular subject (the abuse) is exactly what Barnahus is meant to do, according to the legislation establishing Barnahus. At the same time, the local child welfare services continue to hold overall responsibility for the well-being of the child, implying a holistic approach. Barnahus and the child welfare services thus have a common agenda of helping children but different perspectives on how to implement and improve the assistance to abused children.

\section{Notes}

1. One exception is Johansson (2008), which looked at the external cooperation of Barnahus during the pilot of the Swedish Barnahus.

2. An alternative form of Barnahus involvement is through consultative cases. These are cases where child welfare services contact Barnahus and ask for advice, but the interaction does not lead to an actual Barnahus case. The cases included in this chapter are actual Barnahus cases.

3. In Denmark, a child welfare study is called a $\$ 50$ study due to the section in the legislation (LBK no. 1284 17/11/2015) authorising the study.

4. Theories of holism and reductionism cannot explain all the wariness about the centralisation of expertise. Other aspects, such as a discussion of independence and autonomy between local authorities and the central government of Denmark (see, for instance, Bømler 2012), can play its own part in comments on centralisation and loss of local expertise (Bømler 2012).

\section{References}

Ankestyrelsen. 2015. Evaluering Af overgrebspakken. Copenhagen. Retrieved from http://sim.dk/media/1001951/ankestyrelsens_unders_gelse_af_evaluering_af_overgrebspakken.pdf. 
Bømler, Tina. 2012. Fra specialisering og tilbage til specialisering: Organisering af socialt arbejde i kommunerne. En kort historisk, sociologisk baggrundsanalyse 13(24): 4-13.

Børnerådet. 2015. Erfaringsopsamling: Børns oplevelser af børnehusene. Børnenotat 2/15. (April): 15.

Conte, Jon. 2014. Child Abuse and Neglect Worldwide. Retrieved from http:// kbdk.eblib.com/patron/FullRecord.aspx?p=1693459.

Damsgaard, Signe and Michael Ørtz Christiansen. 2012. Regionale børnehuse til misbrugte børn høster ros. Berlingske Nyhedsbrev.

Ejrnæs, Morten, and Jens Guldager. 2008. Helhedssyn og forklaring i sociologi, socialt, sundhedsfagligt og pedagogisk arbejde. København: Akademisk Forlag.

Ferguson, Iain. 2008. Reclaiming Social Work: Challenging Neo-Liberalism and Promoting Social Justice. Los Angeles: Sage Publications.

Glassow, Trine. 2015. Socialt arbejde med børn og unge udsat for seksuelle overgreb - en praksisnær grundforståelse. In socialt arbejde med børn, unge og familier, eds. Maiken Hougaard, and Lisbeth Ravn Højbjerg, 453-477. København: Hans Reitzel.

Guldager, Jens. 2015. Helhedssyn - teori og modeller på børnefamilieområdet. In Udsatte børn - et helhedsperspektiv, eds. Karen-Asta Bo, Jens Guldager, and Birgitte Zeeberg, 16-59. København: Akademisk.

Harder, Margit. 2011. Helhedssyn - et begrebs udvikling In Helhedssyn i socialt arbejde, Professionsserien, eds. Margit Harder, and Maria A. Nissen, 288. Kbh.: Akademisk Forlag.

Johansson, Susanna. 2008. Myndighetssamverkan i barnahus - organisering, innehåll och process. Delrapport 4 i utvärderingen av nationell försöksverksamhet med barnahus 2006-2007. Research Report in Sociology of Law. vol. 4. Sociology of Law, Lund University.

Johansson, Susanna. 2012. Diffusion and Governance of 'Barnahus' in the Nordic Countries: Report from an On-Going Project. Journal of Scandinavian Studies in Criminology and Crime Prevention 13 (sup1): 69-84.

Kvale, Steinar. 2007. Doing Interviews. Retrieved from https://www.statsbiblioteket.dk/au/\#/search?query=recordID\%3A\%22sb_4346788\%22. Los Angeles: Sage Publications.

Landberg, Åsa. 2009. Boken om barnahus: Samverkan med barnet i centrum, 1. uppl. Stockholm: Gothia.

Laursen, Finn. 2011. Mennesket fra alle sider - Helhedssyn i et figurationsperspektiv. In Helhedssyn i socialt arbejde, Professionsserien, eds. Margit Harder, and Maria Appel Nissen, 111-130. København: Akademisk Forlag. 
Lægsgaard, Mett Marri and Lene Mosegaard Søbjerg. 2012. Evaluering og effektmåling af gruppebehandling for børn/unge, der har været udsat for seksuelle overgreb. Midtvejsrapport. Aarhus: CFK-Center for Kvalitetsudvikling.

Rittel, Horst W. J. and Melvin M. Webber. 1973. Dilemmas in a General Theory of Planning. Policy Sciences 4(2): 155-169.

Socialstyrelsen. 2015. Erfaringsopsamling af børnehusene. Socialstyrelsen, September $2015 \mathrm{http} / / /$ socialstyrelsen.dk/udgivelser/erfaringsopsamling-afde-danske-bornehuse.

Stefansen, Kari, Tonje Gundersen, and Elisiv Bakketeig. 2012. Barnehusevalueringen 2012. Delrapport 2. Oslo: NOVA.

Sundhedsstyrelsen. 2012. Etablering af børnehuse i Danmark - Styrkede rammer for det tvarfaglige og tvarsektorielle samarbejde $i$ sager om overgreb mod børn. Retrieved from http://www.sst.dk/publ/Publ2012/10okt/ EtablBoernehuseDK.pdf.

Uggerhøj, Lars. 2011. Kan helhedssyn ligesom kartofler gå til det hele? Om helhedssyn og perspektiver i socialt arbejde. In Helhedssyn $i$ socialt arbejde, Professionsserien, eds. Margit Harder, and Maria Appel Nissen, 239-264. København: Akademisk Forlag.

Open Access This chapter is licensed under the terms of the Creative Commons Attribution 4.0 International License (http://creativecommons. org/licenses/by/4.0/), which permits use, sharing, adaptation, distribution and reproduction in any medium or format, as long as you give appropriate credit to the original author(s) and the source, provide a link to the Creative Commons license and indicate if changes were made.

The images or other third party material in this chapter are included in the chapter's Creative Commons license, unless indicated otherwise in a credit line to the material. If material is not included in the chapter's Creative Commons license and your intended use is not permitted by statutory regulation or exceeds the permitted use, you will need to obtain permission directly from the copyright holder.

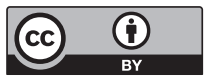

